\title{
Isolation of a virus infectious to the harmful bloom causing microalga Heterosigma akashiwo (Raphidophyceae)
}

\author{
Keizo Nagasaki*, Mineo Yamaguchi \\ Red Tide Biology Section, Red Tide Research Division, Nansei National Fisheries Research Institute, 2-17-5 Maruishi, Ohno, \\ Saeki, Hiroshima 739-04, Japan
}

\begin{abstract}
A virus infecting the harmful bloom causing microalga Heterosigma akashiwo (Raphidophyceae) was isolated from the coastal water of Nomi Bay, Japan, in July 1996. The isolate caused lysis in 2 strains of $H$. akashiwo tested and numerous virus-like particles (VLPs) appeared in the lysed algal culture, whereas virus multiplication was not detected in the healthy culture of $H$. akashiwo without its inoculation. Thus, fulfilling Koch's postulate, it was considered to be a virus and designated HaV (Heterosigma akashiwo virus) clone GSNOU-30. The virus particle is icosahedral, lacking a tail, and $202 \pm 6 \mathrm{~nm}$ (average \pm standard deviation) in diameter with an electron-dense roundish core that is distinct from the capsid. The virus stained positive with DAPI, indicating that it possesses a double stranded DNA genome. The virus proliferated in the protoplasm of the host cell as had previously been observed in $H$. akashiwo cells from a natural red tide population. The virus did not cause lysis of Chattonella antiqua, C. verruculosa or Fibrocapsa japonica (Raphidophyceae) as well as 15 strains of phytoplankton belonging to other classes. It is most noteworthy that 3 strains of $H$. akashiwo isolated from Hiroshima Bay, Japan, were resistant to GSNOU-30, suggesting that the viral infectivity is not species-specific but strain-specific. These results suggest that the virus is involved in the population dynamics of $H$. akashiwo, playing a role as a selector to increase genetic diversity of a host species.
\end{abstract}

KEY WORDS: Red tide - Harmful algal bloom - Lytic virus - Heterosigma akashiwo - Raphidophyceae . Host specificity $\cdot \mathrm{HaV}$

\section{INTRODUCTION}

Heterosigma akashiwo (Raphidophyceae) is a harmful bloom causing flagellate, which causes mortality of cultured fish such as salmon and yellowtail. Red tides of $H$. akashiwo have been recorded in coastal waters of subarctic and temperate areas of both the Northern and the Southern Hemisphere (Pratt 1959, Larsen \& Moestrup 1989, Park et al. 1989, Hallegraeff 1991, Honjo 1993). So far, the physiology and the ecology of $H$. akashiwo have been considerably studied and an elucidation of the mechanism to initiate a $H$. akashiwo red tide has been achieved (Yamochi 1983, 1984, 1989, Honjo 1993). In contrast, the disintegration mechanisms of $H$. akashiwo red tides have only been superficially

·E-mail: nagasaki@nnf.affrc.go.jp studied. Several characteristics in the termination process of $H$. akashiwo red tides, e.g. cyst formation, cessation of vertical migration and changes in the growth potential for individual cells, have been reported (Itakura et al. 1996, Nagasaki et al. 1996), but the disintegration mechanisms of red tides have been insufficiently explained up to the present.

VLPs (virus-like particles) have been observed in more than 50 species in at least 12 of the 14 recognized classes of eucaryotic algae (Reisser 1995), including Heterosigma akashiwo in a natural red tide population. The proportion of $H$. akashiwo cells harboring VLPs rose specifically in the final stage of red tides. In thin sections, VLPs were 165 to $180 \mathrm{~nm}$ in diameter, icosahedral, with an electron-dense roundish core distinct from the capsid, and lacking a tail (Nagasaki et al. 1994a, b). Although, on the basis of these observations, viral mortality has been suggested to be an important factor in the dis- 
integration process of $H$. akashiwo red tides, no evidence for infectivity of the VLP has been obtained.

In recent years, 5 viruses which are infectious to eucaryotic microalgae in the marine environment, Micromonas pusilla (Prasinophyceae), Emiliania huxleyi (Prymnesiophyceae), Aureococcus anophagefferens (Chrysophyceae), Chrysochromulina spp. (Prymnesiophyceae) and Phaeocystis pouchetii (Prymnesiophyceae) have been isolated, 3 of them originating from natural seawaters where the host species had bloomed (Cottrell \& Suttle 1991, Milligan \& Cosper 1994, Suttle \& Chan 1995, Bratbak et al. 1996, Jacobsen et al. 1996). Lytic activities of the viruses suggest they can be involved in regulating the bloom dynamics of the host species, whereas their tangible role in aquatic ecosystems still remains enigmatic. In the present paper, we report the first data on isolation, lytic activity and host specificity of a virus infecting $H$. akdshiwo. To our knowledge, this is the first report on a virus infecting a Raphidophyte.

\section{MATERIALS AND METHODS}

Algal cultures. The strains of Heterosigma akashiwo and the other microalgae used in this study are listed in Table 1. All of them are clonal, established by the micropipetting method or an extinction dilution method. H. akashiwo strains were grown at $20^{\circ} \mathrm{C}$ and the other algal strains were grown at 15 or $20^{\circ} \mathrm{C}$ in modified SWM3 medium (Chen et al. 1969, Itoh \& Imai 1987 ) enriched with $2 \mathrm{nM} \mathrm{Na}_{2} \mathrm{SeO}_{3}$ under a 14:10 h light:dark cycle of ca $45 \mu \mathrm{mol}$ photons $\mathrm{m}^{-2} \mathrm{~s}^{-1}$ with cool white fluorescent illumination.

Isolation of lytic viruses. A seawater sample collected in Nomi Bay, Kochi Prefecture, Japan, on 11 July 1996, containing 35400 cells ml ${ }^{-1}$ of Heterosigma akashiwo, was initially kept at $4^{\circ} \mathrm{C}$ and sent to the laboratory within $24 \mathrm{~h}$. Treatment in the laboratory was modified from the method of Bratbak et al. (1996) and Jacobsen et al. (1996); five $50 \mathrm{ml}$ aliquots of the natural seawater were placed in petri dishes, exposed to UV radiation (254 $\mathrm{nm}$ wavelength, Toshiba GL15) for 0,30 , 60,90 and $120 \mathrm{~s}$ and incubated for $2 \mathrm{~d}$ at $20^{\circ} \mathrm{C}$ as mentioned above. Then, each sample was filtered through a $0.2 \mu \mathrm{m}$ Nuclepore membrane filter. $200 \mu \mathrm{i}$ of each filtrate was inoculated into a $5 \mathrm{ml}$ culture of $\mathrm{H}$. akashiwo GS95, which was incubated under the conditions mentioned above. The cultures were checked by light microscopy every day to examine whether cell lysis occurred or not.

Algicidal factors were isolated by the 2-times extinction dilution method (Suttle \& Chan 1993). 10-fold dilutions of the supernatant of each lysate were made into

Table 1. Susceptibility of algal strains against HaV GSNOU-30 infection. +: lysed by HaV GSNOU-30; -: not lysed

\begin{tabular}{|c|c|c|c|c|}
\hline & \multirow[t]{2}{*}{ Species } & \multicolumn{2}{|c|}{ Isolation } & \multirow[t]{2}{*}{ Susceptibility } \\
\hline & & Locality & Date & \\
\hline Raphidophyceae & $\begin{array}{l}\text { Heterosigma akashiwo GS95 } \\
\text { Heterosigma akashiwo UR94 } \\
\text { Heterosigma akashiwo H94222 } \\
\text { Heterosigma akashiwo H94608 } \\
\text { Heterosigma akashiwo H95623 } \\
\text { Fibrocapsa japonica-1 }{ }^{\text {a }} \\
\text { Chattonella antiqua OC-B5 } \\
\text { Chattonella verruculosa M }\end{array}$ & $\begin{array}{l}\text { Gakasho Bay } \\
\text { Uranouchi Bay } \\
\text { Hiroshima Bay } \\
\text { Hiroshima Bay } \\
\text { Hiroshima Bay } \\
\text { Harima Nada } \\
\text { Osaka Bay } \\
\text { Hiroshima Bay }\end{array}$ & $\begin{array}{l}\text { May } 1995 \\
\text { May } 1995 \\
\text { Feb } 1994 \\
\text { Jun } 1994 \\
\text { Jun } 1995 \\
\text { Oct } 1985 \\
\text { Sep } 1985 \\
\text { May } 1993\end{array}$ & $\begin{array}{l}+ \\
+ \\
- \\
- \\
- \\
- \\
- \\
-\end{array}$ \\
\hline Dinophyceae & $\begin{array}{l}\text { Heterocapsa triquetra } \mathrm{H} 9104 \\
\text { Heterocapsa circularisquama HA92-1 } \\
\text { Gymnodinium mikimotoi G303-ax2 } \\
\text { Prorocentrum triestinum } \mathrm{H} 9109^{\mathrm{a}} \\
\text { Prorocentrum dentatum } \mathrm{H} 9608^{\mathrm{a}} \\
\text { Alexandrium tamarense-1 }{ }^{a}\end{array}$ & $\begin{array}{l}\text { Hiroshima Bay } \\
\text { Ago Bay } \\
\text { Suo Nada } \\
\text { Hiroshima Bay } \\
\text { Hiroshima Bay } \\
\text { Hiroshima Bay }\end{array}$ & $\begin{array}{l}\text { Apr } 1991 \\
\text { Dec } 1992 \\
\text { Jul } 1985 \\
\text { Sep } 1991 \\
\text { Aug } 1996 \\
\text { Nov } 1995\end{array}$ & $\begin{array}{l}- \\
- \\
- \\
- \\
-\end{array}$ \\
\hline Prymnesiophyceae & $\begin{array}{l}\text { Isochrysis galbana } \\
\text { Pavlova lutheri }\end{array}$ & $\begin{array}{l}\text { Unknown } \\
\text { Unknown }\end{array}$ & $\begin{array}{l}\text { Unknnwn } \\
\text { Unknown }\end{array}$ & $\begin{array}{l}- \\
-\end{array}$ \\
\hline Cryptophyceae & Rhodomonas ovalis & Coast of Fukuyama & Jun 1967 & - \\
\hline Bacillariophyceae & $\begin{array}{l}\text { Skeletonema costatum SK-1 } \\
\text { Thalassiosira sp. Th-2 } \\
\text { Chaetoceros didymus Ch-4 } \\
\text { Ditylum brightwellii }\end{array}$ & $\begin{array}{l}\text { Hiroshima Bay } \\
\text { Hiroshima Bay } \\
\text { Hiroshima Bay } \\
\text { Hiroshima Bay }\end{array}$ & $\begin{array}{l}\text { Mar } 1989 \\
\text { Feb } 1989 \\
\text { Mar } 1989 \\
\text { Mar } 1989\end{array}$ & $\begin{array}{l}- \\
- \\
-\end{array}$ \\
\hline Prasinophyceae & Pyramimonas sp. ${ }^{a}$ & Hiroshima Bay & Jun 1994 & - \\
\hline Chlorophyceae & Oltomannsielopsis viridis ${ }^{a}$ & Osaka Bay & Oct 1993 & - \\
\hline
\end{tabular}


successive $150 \mathrm{\mu l}$ drops of Heterosigma akashiwo GS95 cell suspension with 8 replicates at each dilution. Supernatant of the algal lysate in the highest dilution of the first assay was carried over to the second extinction dilution assay. Finally, supernatant of the lysate in the highest dilution of the second assay was inoculated to a $50 \mathrm{ml}$ fresh culture of $H$. akashiwo GS95. The resultant lysate was combined with $0.2 \%$ of sodium azide, stored at $4^{\circ} \mathrm{C}$ in the dark, and tentatively designated as 'an original viral suspension' in the present study. All incubation was carried out under the conditions mentioned above. In parallel, on the basis of the resultant numbers of wells with evidence of lysis in each dilution, the concentration of algicidal factors was calculated as MPN (most probable number) in each assay, using the computer program developed by Nishihara et al. (1986).

Virus particles in the lysates were trapped onto a $0.02 \mu \mathrm{m}$ pore size filter (Anodisc 25, Whatman International Ltd), stained with DAPI (4',6-diamidino-2phenylindole) and observed under UV excitation Virus particles negatively stained with uranyl acetate were also observed by transmission electron microscopy.

Host range. The host range of the isolated virus was tested by adding $50 \mu \mathrm{l}$ of the original viral suspension: (1) without any treatment, (2) filtered through a $0.2 \mu \mathrm{m}$ pore size filter (DISMIC-25, Advantec), (3) filtered through a $0.1 \mu \mathrm{m}$ pore size filter (Anotop ${ }^{\mathrm{TM}} 25$, Anotec) or (4) treated at $100^{\circ} \mathrm{C}$ for $5 \mathrm{~min}$, to $1 \mathrm{ml}$ cultures of the exponentially growing algal strains listed in Table 1. The cultures were observed by light microscopy. Cultures that were not lysed after $10 \mathrm{~d}$ were considered to be unsuitable hosts for the virus.

Viral effect on Heterosigma akashiwo cultures. $50 \mu \mathrm{l}$ aliquots of the original viral stock suspension were treated as in (1) to (4) above and inoculated into triplicate cultures $(4 \mathrm{ml})$ of $H$. akashiwo GS95 and $H$. akashiwo UR94 (Table 1) in the exponentially growing phase. Growth of $H$. akashiwo was monitored using a fluorometer (Turner Designs). After lysis of algal cells, an aliquot of each culture was prepared for transmission electron microscopy according to the method of Hara \& Chihara (1982).

\section{RESULTS AND DISCUSSION}

In the first screening process, cell lysis was detected in the Heterosigma akashiwo GS95 cultures inoculated with the natural seawater exposed to UV light for 0,30 and $60 \mathrm{~s}$, but not 90 or $120 \mathrm{~s}$. Supernatants of the lysed cultures were carried over to the first extinction dilution assay. The resultant algal lysates contained $1.90 \times$ $10^{6}$ to $5.10 \times 10^{6} \mathrm{ml}^{-1}$ of algicidal factors. Each lysate in the highest dilution of the first assay was again carried over to the second extinction dilution assay to be isolated; the probability that more than 1 algicidal factor occurred in the final lysates is $<0.0106$.

The resultant algal lysates contained numerous particles stainable with DAPI. On the other hand, the particles were not observed in the healthy culture of Heterosigma akashiwo. Thus, the particles possessing double stranded DNA (dsDNA) appear capable of proliferating in $H$, akashiwo cultures. Then, they were tentatively designated GSNOU-0, GSNOU-30 and GSNOU-60 according to the UV irradiation time, respectively, and GSNOU-30 was further examined in the present study.

Cell lysis was caused in Heterosigma akashiwo GS95 and UR94 strains inoculated with the original stock suspension of GSNOU-30 without treatment or with filtration through a $0.2 \mu \mathrm{m}$ filter. In contrast, this algicidal activity was lost by either filtration through a $0.1 \mu \mathrm{m}$ filter or heat treatment, indicating that the algicidal factor is sized presumably between 100 and $200 \mathrm{~nm}$ and is heat-labile (Fig. 1).
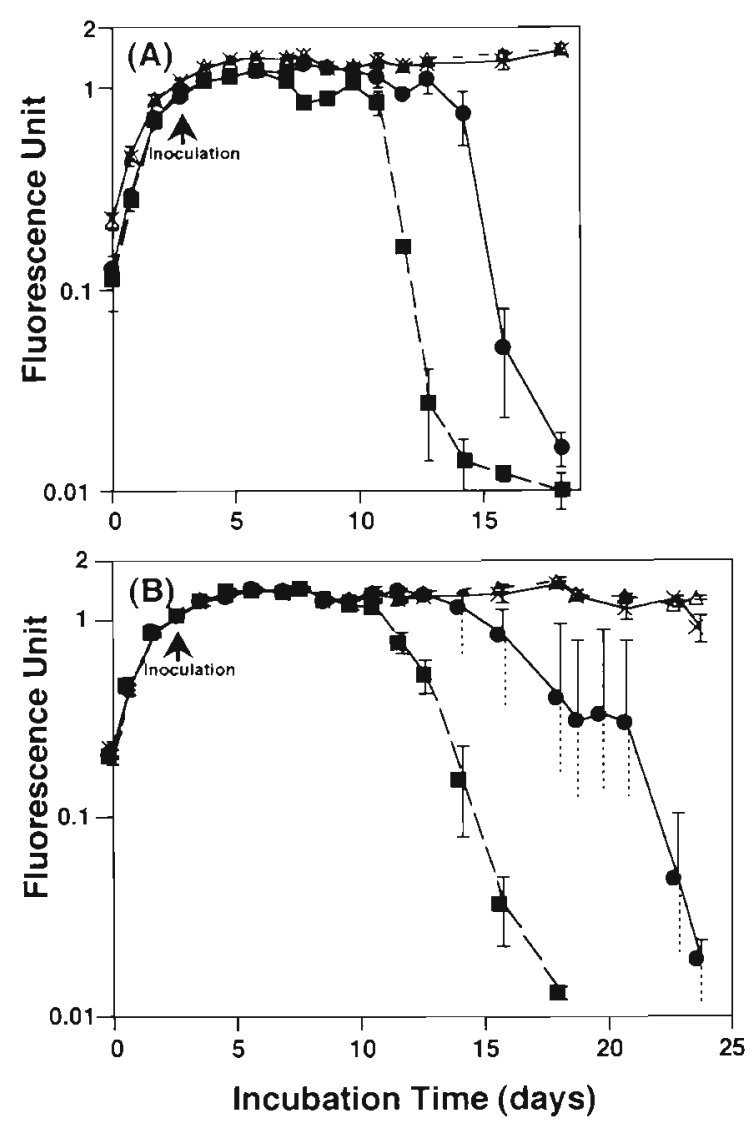

Fig. 1. Growth of (A) Heterosigma akashiwo GS95 and (B) $H$. akashiwo UR94 inoculated with HaV GSNOU-30 with no treatment ( $\square$ ), filtered through a $0.2 \mu \mathrm{m}$ filter ( ), a $0.1 \mu \mathrm{m}$ filter $(x)$ and with heat treatment at $100^{\circ} \mathrm{C}$ for $5 \mathrm{~min}(\Delta)$. Error bars indicate SD 

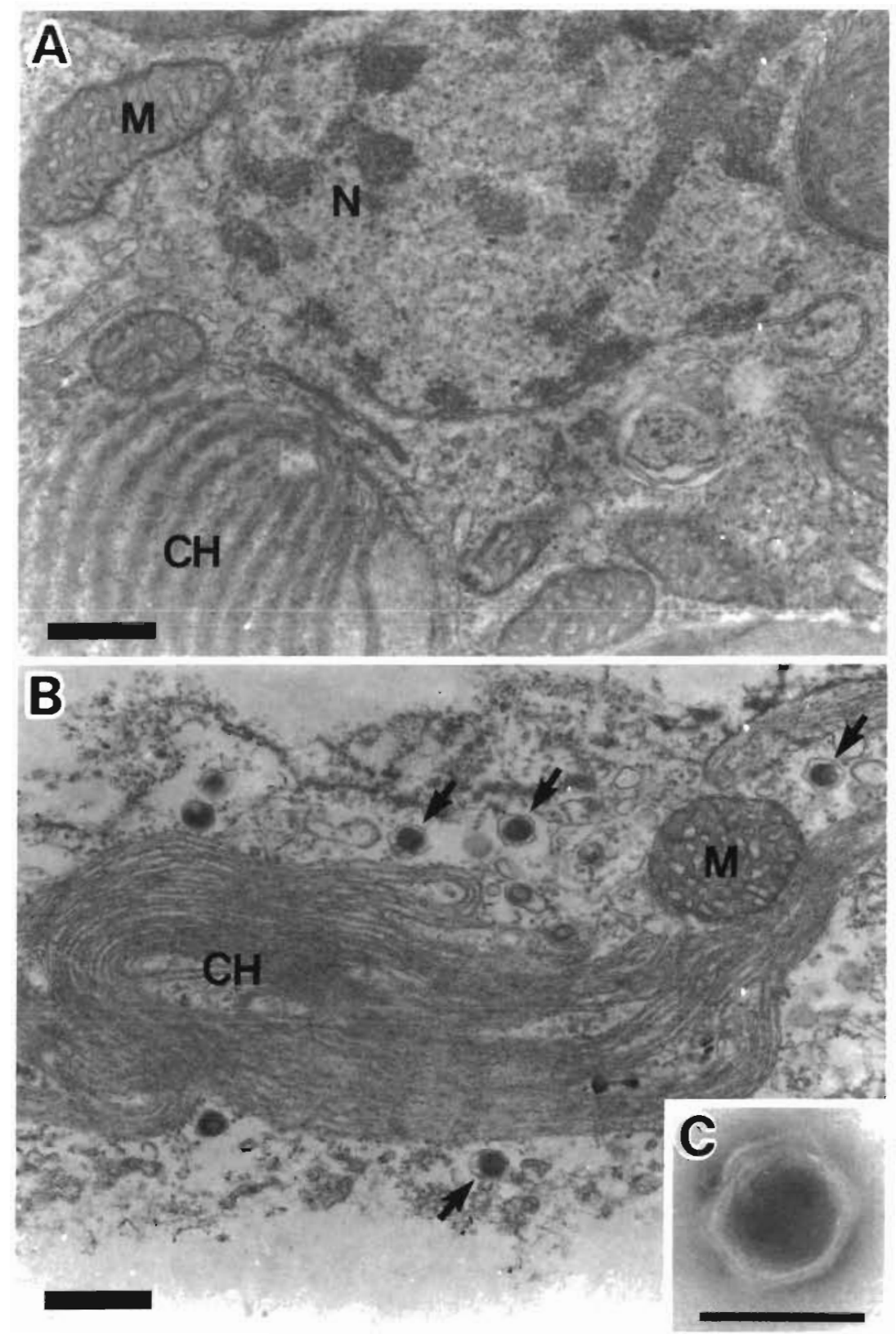

Fig. 2. Transmission electron micrograph of Heterosigma akashiwo UR94, $13 \mathrm{~d}$ after inoculation with HaV GSNOU-30 (A) with or (B) without heat treatment, and of $(C)$ the negatively stained virus particle. Each organella is intact in (A). In contrast, a chloroplast is highly degraded and virus-like particles (arrows) are

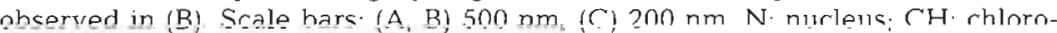
plast; $M$ : mitochondrion

VLPs were detected by transmission electron microscopy in the lysed cultures inoculated with the original stock suspension with no treatment (Fig. 2B) and filtration through a $0.2 \mu \mathrm{m}$ filter. In contrast, no viral replication was detected in the cultures inoculated with the original stock suspension with filtration through a $0.1 \mu \mathrm{m}$ filter or heat-treated (Fig. 2A). The VLP was
$202 \pm 6 \mathrm{~nm}$ laverage \pm standard deviation) in diameter (Fig. 2C) and pentagonal or hexagonal in crosssection, indicating icosahedral symmetry (Fig. 2B). It harbored an electron-dense roundish core that was distinct from the capsid and no taillike structure was observed (Fig. 2B).

These results, (1) VLPs were observed in the lysed culture, (2) the algicidal effect was transferrable to a fresh algal culture and (3) VLPs were not found in healthy culture, fulfill Koch's postulates. Therefore, we concluded that the algicidal factor is both morphologically and physiologically a Iytic dsDNA virus. The virus infecting Heterosigma akashiwo has been designated 'HaV (Heterosigma akashiwo virus) GSNOU-30'.

In the first step of the viral lysis, the infected cell became roundish, lost mobility, settled to the bottom of the incubation chamber, then was lysed and discolored gradually (Fig. 3). On the basis of these observations, it is suggested that infected cells sink to lower layers in the water column as observed in a natural red tide population (Nagasaki et al. 1996). The relationship between the cessation of upward migration of Heterosigma akashiwo cells in the final stage of a red tide and the loss of mobility caused by viral infection is noteworthy.

No algal lysis was observed for Fibrocapsa japonica, Chattonella antiqua, C. verruculosa (Raphidophyceae), Heterocapsa triquetra, $H$. circularisquama, Prorocentrum triestinum, $P$. dentatum, Alexandrium tamarense (Dinophyceae), Isochrysis galband, Pavlova Iutheri (Prymnesiophyceae), Rhodomonas ovalis (Cryptophyceae), Skeletonema costatum, Thalassiosira sp., Chaetoceros didymus, Ditylum brightwellii (Bacillariophyceae), Pyramimonas sp. (Prasinophyceae), Oltomannsiellopsis viridis (Chlorophyceae) inoculated with GSNOU-30. On the other hand, 3 strains of Heterosigma akashiwo (strains H94222, H94608 and H95623) isolated from Hiroshima Bay were resistant to HaV GSNOU-30 (Table 1). Thus, infectivity of $\mathrm{HaV}$ GSNOU-30 is not species-specific but strain-specific, showing the first example of pheno- 
typic diversity among $H$. akashiwo strains in terms of viral infection. If the lytic virus plays a role as a selector to increase genetic diversity of a host species (Suttle \& Chan 1993, Waterbury \& Valois 1993), both ecological and physiological studies for an algal virus should be designed to use several strains of the host species.

Furthermore, the viruses isolated in the present study and the VLPs observed in the Heterosigma akashiwo cells in the red tide seawater sample (Nagasaki et al. $1994 \mathrm{a}, \mathrm{b})$ highly resembled each other in morphology (Fig. 2), suggesting the viral mortality in $H$. akashiwo blooms involving viral lytic activity.

What determines the sensitivity and resistance of a host cell remains unclear. Although there is no evidence which demonstrates the lysogeny in algal viruses infectious to eucaryotic hosts, one possible explanation is that immunity against a virus infection could be acquired by lysogeny of the same (or closely related) virus. Another possibility is a biochemical difference at the cell surface of host strains which can result in resistance against viral infection.

It is also indistinguishable whether algicidal activity originated from a lytic virus or a temperate virus in the sample seawater. Indeed, UV treatment was made in order to induce the latter into the former, its practical effect for induction has not been clearly elucidated yet. In the present study, the algicidal activity had already existed in the natural seawater sample. However, it does not necessarily exclude the possibility of induction by UV treatment in the case of GSNOU-30 and GSNOU-60.

It is fascinating to speculate on the mechanism of viral resistance and lysogeny. As well as the 5 microalgal viruses isolated so far, $\mathrm{HaV}$ is also expected to be a suitable material for these studies.

Acknowledgements. Dr T Uchida, Dr T. Kamiyama, Mr. S Itakura (Nansei Natl. Fish. Res. Inst.), Dr I. Imai (Kyoto Univ.) and Dr H. Iwasaki (formerly Mie Univ.) graciously provided some of the algal cultures tested in the present study. We express our sincere thanks to Mr S. Oda, Kochi Prefectural Fisheries Experimental Station, for providing the water samples. We also thank. S. Norland (Univ. Bergen) for preparation of MPN calculation by computer. This work was supported by funding from the Fisheries Agency of Japan.

\section{LITERATURE CITED}

Bratbak G, Willson W, Heldal M (1996) Viral control of Emiliania huxleyi blooms? J Mar Syst 9:75-81

Chen LCM, Edelstein T, McLachlan J (1969) Bonnemaisonia hamifera Hariot in nature and in culture. J Phycol 5:211-220

Cottrell MT, Suttle CA (1991) Wide-spread occurrence and clonal variation in viruses which cause lysis of a cosmopolitan, eucaryotic marine phytoplankter, Micromonas pusilla. Mar Ecol Prog Ser 78:1-9

Hallegraeff GM (1991) Aquaculturists' guide to harmful Australian microalgae. CSIRO, Hobart

Hara Y, Chihara M (1982) Ultrastructure and taxonomy of Chattonella (Class Raphidophyceae) in Japan. Jap J Phycol 30:47-56 (in Japanese with English abstract)

Honjo T (1993) Overview on bloom dynamics and physiological ecology of Heterosigma akashiwo. ln: Smayda TJ, Shimizu Y (eds) Toxic phytoplankton blooms in the sea. Elsevier, New York, p 33-41

Itakura S, Nagasaki K. Yamaguchi M, Imai I (1996) Cyst formation in the red tide flagellate Heterosigma akashiwo (Raphidophyceae). J Plankton Res 18:1975-1979

Itoh K, Imai I (1987) Rafido so (Raphidophyceae). In: Japan Fisheries Resource Conservation Association (ed) A guide for studies of red tide organisms. Shuwa, Tokyo, p $122-130$ (in Japanese)

Jacobsen A, Bratbak G, Heldal M (1996) Isolation and characterization of a virus infecting Phaeocystis pouchetii (Haptophyceae). J Phycol 32:923-927

Larsen J, Moestrup $\varnothing$ (1989) Guide to toxic and potentially toxic marine algae. Fish Inspection Service, Ministry of Fisheries, Copenhagen

Milligan KLD, Cosper EM (1994) Isolation of virus capable of lysing the brown tide microalga, Aureococcus anophagefferens. Science 266:805-807

Nagasaki K, Ando M, Imai I, Itakura S, Ishida Y (1994a) Viruslike particles in Heterosigma akashiwo (Raphidophyceae): a possible red tide disintegration mechanism. Mar Biol 119:307-312

Nagasaki K, Ando M, Itakura S, Imai I, Ishida Y (1994b) Viral mortality in the final stage of Heterosigma akashiwo (Raphidophyceae) red tide. J Plankton Res 16: 1595-1599

Nagasaki K, Itakura S, Imai I, Nakagiri S, Yamaguchi M (1996) The disintegration process of a Heterosigma akashiwo 
(Raphidophyceae) red tide in northern Hiroshima Bay Japan, during the summer of 1994. In: Yasumoto $T_{\text {, }}$ Oshima $Y$, Fukuyo $Y$ (eds) Harmful and toxic algal blooms. Intergovernmental Oceanographic Commission of UNESCO, Paris, p 251-254

Nishihara T, Kurano N, Shinoda S (1986) Calculation of most probable number for enumeration of bacteria on a microcomputer. Eisei Kagaku 32:226-228 (in Japanese with English abstract)

Park JS, Kim HG, Lee SG (1989) Studies on red tide phenomena in Korean coastal waters. In: Okaichi T, Anderson DM, Nemoto T (eds) Red tides: biology, environmental science and toxicology. Elsevier, New York, p 37-40

Pratt DM (1959) The phytoplankton of Narragansett Bay. Limnol Oceanogr 4:425-440

Reisser W (1995) Phycovirology: aspects and prospect of a new phycological discipline. In: Weissner $W$, Schnepf $E$, Starr RC (eds) Algae, environment and human affairs. Biopress Ltd, Bristol, p 143-158

Suttle CA, Chan AM (1993) Marine cyanophages infecting oceanic and coastal strains of Synechococcus: abundance,

Responsible Subject Editor: Gunnar Bratbak, Bergen, Norway morphology, cross-infectivity and growth characteristics. Mar Ecol Prog Ser 92:99-109

Suttle CA, Chan AM (1995) Viruses infecting the marine Prymnesiophyte Chrysochromulina spp.. isolation, preliminary characterization and natural abundance. Mar Ecol Prog Ser 118:275-282

Waterbury JB, Valois FW (1993) Resistance to co-occurring phages enables marine Synechococcus communities to coexist with cyanophages abundant in seawater. Appl Environ Microbiol 59:3393-3399

Yamochi S (1983) Mechanisms for outbreak of Heterosigma akashiwo red tide in Osaka Bay, Japan. Part 1. Nutrient factors involved in controlling the growth of Heterosigma akashiwo Hada. J Oceanogr Soc Jap 39:310-316

Yamochi S (1984) Mechanisms for outbreak of Heterosigma akashiwo red tide in Osaka Bay, Japan. Part 3. Release of vegetative cells from bottom mud. J Oceanogr Soc Jap 40 : $343-348$

Yamochi S (1989) Mechanisms for outbreak of Heterosigma akashiwo red tide in Osaka Bay, Japan. Bull Osaka Pref Fish Exp Stn 8:1-110

Manuscript received: January 27, 1997

Revised version accepted: April 30, 1997 